\title{
Active vs. Passive Microteaching Lesson Study: Effects on Pre-service Teachers' Technological Pedagogical Content Knowledge
}

\author{
Billy A. Danday \\ Leyte Normal University \\ Tacloban City, Philippines
}

\begin{abstract}
The effects of the Active and Passive Microteaching Lesson Study (MLS) on the Technological Pedagogical Content Knowledge (TPCK) of the 18 pre-service Physics teachers were investigated using a pre-test-post-test quasi-experimental design. Scores from the contentbased TPCK test, interview responses, and journal entries were analyzed using both quantitative and qualitative techniques, specifically, the Mann-Whitney U test, the Wilcoxon Signed Ranks test, the conceptual content analysis, and the constant comparative method. Results revealed that the Active Microteaching Lesson Study (Active MLS) provided more beneficial effects on the pre-service Physics teachers' overall TPCK and certain components than the Passive MLS. The implications of the findings to research and practice were discussed. Recommendations for future research were also provided.
\end{abstract}

Keywords: lesson study (LS), microteaching, pre-service teachers, science teaching, technological pedagogical content knowledge (TPCK).

\section{Introduction}

The current educational paradigm views teaching competence as a product of the integrated knowledge on technology, pedagogy, and content (Cox, 2008; Koehler, Mishra, Akcaoglu, \& Rosenberg, 2013; Koehler, Mishra, \& Cain, 2013). Mishra and Koehler (2006) coined this framework as Technological Pedagogical Content Knowledge (TPCK) which has proliferated in various aspects of education since its conception.

Research has shown that a host of benefits can be gained with improved TPCK of pre-service teachers. Such are enhanced instructional materials and better learning assessment (Ervin, 2014; Tokmak, Yelken, \& Konokman, 2013), enriched technological literacy, and effective utilization of educational technology (Alev, Karal-Eyuboglu, \& Yigit, 2012; Archambault \& Crippen, 2009; Cavin, 2007; Chai, 
Koh, \& Tsai, 2010; Chang, Tsai, \& Jang, 2014; Chew \& Lim, 2013; Haley-Mize, 2011; Ozturk, 2012).

Engaging in a collaborative instructional approach such as the Lesson Study may not be globally popular but it promises great potential in developing preservice teachers' TPCK (Fernandez, 2002; Lewis, 2002; Lewis, Perry, \& Hurd, 2009). Scholars have reported positive impressions of the microteaching-based Lesson Study in diverse dimensions of the educational milieu like improving instructional practices and competencies (Elipane, 2012; Gurl, 2009), transforming knowledge of the Nature of Science (NOS) into practical classroom praxis (McDowell, 2010), and imposing a positive influence in students' academic performance and critical thinking (Barrett, Riggs, \& Ray, 2013; Lucenario, Yangco, Punzalan, \& Espinosa, 2016; Quilario, 2014; Teele, Maynard, \& Marcoulides, 2015). Microteaching does not only provide the prospective teachers a first-hand experience of a classroom setting but it also reinforces their professional competence (Akkus \& Uner, 2017; Remesh, 2013; Sentumbwe, 2018).

\subsection{Research Purpose}

In light of the research endeavors devoted to informing the constructs of the Technological Pedagogical Content Knowledge and Lesson Study, a dearth in the literature exists that illuminate the pre-service Physics teacher education. No study has investigated the probable effects of the Passive and Active Microteaching Lesson Study on the overall TPCK and on specific knowledge domains of the pre-service Physics teachers. This research attempts to address the aforementioned gap in knowledge. Further, it aims to scaffold the teaching competence of the pre-service teachers and to develop a spirit of interdependence among them through a collaborative instructional planning approach.

\section{Related Literature}

\subsection{Technological Pedagogical Content Knowledge (TPCK)}

The TPCK is a comprehensive knowledge domain concerning didactic competence on three educational components - educational technology, instructional method, and subject matter. It refers to the integrated knowledge of the utilization of educational technology that is suited to the instructional methods and strategies in teaching a particular content (Koehler et al., 2013; Koehler et al., 2009).

The TPCK framework consists of six sub-domains that explicitly depict a certain knowledge as shown in Figure 1. Three of which are fundamental knowledge sub-domains while the other three are an amalgamation of two of these fundamental knowledge sub-domains. The Technological Knowledge (TK) denotes the awareness of the existence and the understanding of the functions of the technologies used for instruction. In this study, it also involves the utilization and the production of both the modern technologies (e.g. computer hardware 
and software, multimedia, and LCD projector) and conventional educational technologies (e.g. replica, models, and visual aids). The Pedagogical Knowledge $(\mathrm{PK})$ indicates knowledge of the instructional methods and strategies, as well as of the classroom management, and of learning evaluation techniques. Meanwhile, the Content Knowledge (CK) specifies the extent of understanding on the subject matter that one teaches.

The Technological Pedagogical Knowledge (TPK) is the teacher's knowledge of the use of educational technologies befitting the instructional strategies employed by the teacher. The Technological Content Knowledge (TCK), on the other hand, is the interplay between the technological knowledge and the content knowledge which indicates the teacher's proficiency in selecting and utilizing technologies that are suited to certain content. Finally, the Pedagogical Content Knowledge (PCK) denotes the understanding of the various instructional methodologies that are suitable for the subject matter.

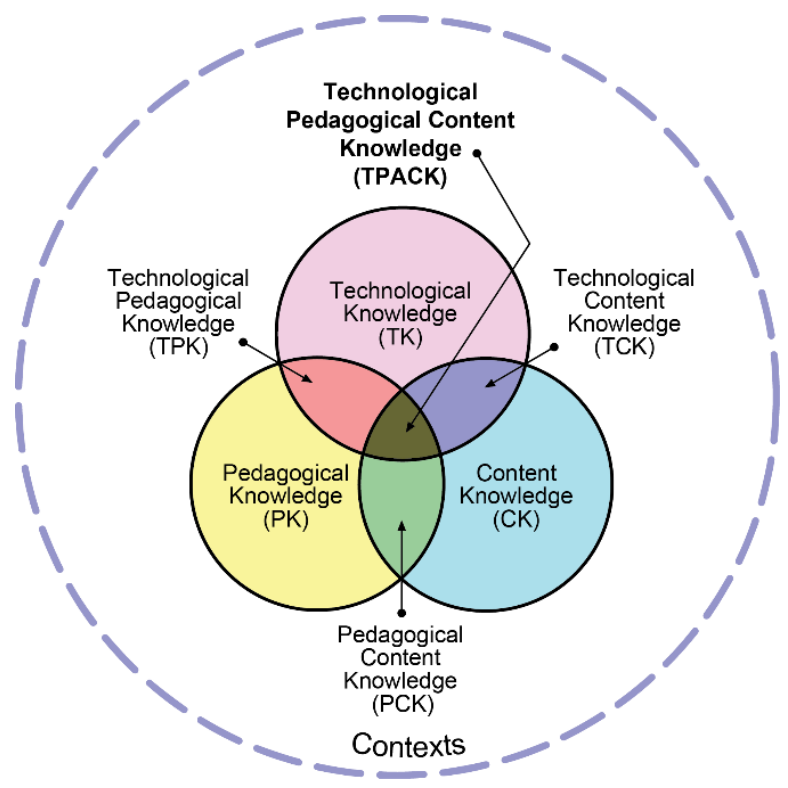

Figure 1: The TPCK framework. Reproduced by permission of the publisher, $@ 2012$ by tpack.org, http://tpack.org

Literature has shown that the TPCK can be assessed quantitatively or qualitatively. A popular quantitative method is the utilization of a self-report survey instrument that has been applied in a number of studies due to practicality and convenience (Chew \& Lim, 2013; Harris, Phillips, Koehler, \& Rosenberg, 2017; Schmidt, Baran, Thompson, Koehler, Mishra, \& Shin, 2009). An online administration of the said instrument has targeted an extensive sample size of research participants, hence, allowed Archambault and Crippen (2009) to assess the TPCK of the online distance instructors of the K-12 curriculum across the USA. Meanwhile, qualitative analyses on interview responses, performance assessment, and other learners' outputs have paved the way for unfolding preservice teachers' TPCK in a different light. Cavin (2007), Mudzimiri (2012), Niess 
(2005), Ozturk (2012), Terpstra (2009) employed qualitative techniques in extensively describing the TPCK development of pre-service teachers.

Scholars have reported diverse effects of various interventions aimed at enhancing the TPCK of pre-service teachers. Technology-based platforms often provide positive influences on TPCK and some of its components (Chai et al., 2010; Terpstra, 2009). Cavin (2007) has integrated technology in a Microteaching Lesson Study (MLS) that pointed out remarkable transformations on participants' views on the educational use of technologies and their notable experiences with the collaborative instructional approach.

Research, likewise, has revealed that a number of factors are at play in the development of the TPCK among pre-service teachers. Holland (2014), for example, has conveyed that intrinsic and extrinsic motivation are positively correlated with particular TPCK components. Nathan (2009) has further expressed that the technology integration self-efficacy (TISE) of pre-service teachers is moderately correlated to their TPCK.

The rich literature has established a solid underpinning of the TPCK construct. Few domains, however, remain unknown and some questions still await to be answered. There exists no study examining the pre-service teachers' TPCK utilizing a content-based written test, specifically, in Physics. Moreover, there is dearth in literature scrutinizing the differential effects of a collaborative instructional planning approach employing active and passive microteaching.

\subsection{Lesson Study}

The contemporary educational practices chiefly embody the individualistic instructional paradigm. Many educational institutions leave the teachers on their own to plan, design, and implement their lessons. Apart from the rest, the inservice Japanese educators have a distinctive system of carrying out their instructional goals - a collaborative instructional approach known as the jugyokenkyu or the Lesson Study (Fernandez, 2002). The Lesson Study is a literal English translation of the Japanese terms jugyo [lesson] and kenkyu [study].

A detailed Lesson Study process consists of the following stages: (1) establishing goals, (2) planning the lesson, (3) planning the study design, (4) executing the instructional plan, (5) deliberating the lesson implementation, (6) modifying the instructional plan, (7) implementing the revised instructional plan, (8) deliberating the second implementation, and (9) keeping study records (Cavin, 2007; Cerbin \& Kopp, 2006; Chew \& Lim, 2013; Fernandez, 2002). It has been stressed that the main goal of the Lesson Study is to understand how the students learn the lesson, not to determine what they have learned (Cerbin \& Kopp, 2006).

Scholars have revealed successes of the adaptation of the Lesson Study framework in various fields of the educational milieu (Fernandez, 2002; Kolenda, 2007; Lewis, 2002; Lewis et al., 2009). In the pre-service teaching program, Elipane (2012) and Gurl (2009) have reported desirable effects of the 
Lesson Study in the formation of pre-service teachers' pedagogical capabilities, practices, and skills. Likewise, McDowell (2010) has contended that Lesson Study can aid in the transmission of Nature of Science (NOS) into practical engagements. In students' learning, a positive impact has been accounted of the Lesson Study on academic performance and critical thinking (Barrett et al., 2013; Kanellopoulou, E.M., Darra, M., 2018; Lucenario et al., 2016; Quilario, 2014; Teele et al., 2015).

Technology-based Lesson Study interventions in a teacher education program have gained the framework with impressive stature. Chew \& Lim (2013) have investigated the use of Geometer's Sketchpad (GSP) in mathematics instruction employing the Lesson Study (LS). The self-report surveys have indicated improved technological pedagogical content knowledge of the pre-service Mathematics teachers. In the same light, Cavin (2007) have asserted that the preservice teachers can acquire a better appreciation of educational technologies that are integrated with a constructivist instructional style when they are exposed to the Microteaching Lesson Study.

Literature has shown an extensive application of an active microteaching-based Lesson Study. Microteaching is a technique that allows pre-service teachers rehearse teaching procedures and learn essential teaching skills in a controlled environment (Akkus \& Uner, 2017; Remesh, 2013). Small groups of pre-service teachers create a classroom scenario where one acts as a "teacher" while the rest act as "students".

Supporting the findings of the studies that have integrated the microteaching in the Lesson Study, other researches have established the indispensable role of the microteaching in the development of the professional skills of the pre-service teachers. Scholars have revealed improvements in pre-service teachers' competence in lesson planning, communication skills, classroom management, construction of audiovisual materials, subject-matter knowledge, assessment methods, questioning skills, student motivation, and self-reflection when they were exposed to microteaching sessions (Akkus \& Uner, 2017; Remesh, 2013; Sentumbwe, 2018).

It must be noted that in this study, microteaching is dissected into two types the active and the passive microteaching. The Active Microteaching is characterized by the actual teaching implementation of the instructional plan, that is, a pre-service teacher acts as a "teacher" in at least one of the teaching sessions in the Lesson Study process. The Passive Microteaching, on the other hand, is typified by a no-teaching Lesson Study procedure. The pre-service teacher simply acts as a "student" throughout the intervention.

There is a substantial data casting light upon the integration of the Active Microteaching Lesson Study in Mathematics education, nevertheless, there is inadequate knowledge on its application in the pre-service Physics education. More importantly, no study has delved into the comparative effects of the Active 
and the Passive Microteaching Lesson Study on the TPCK of pre-service Physics teachers that employs a valid and domain-specific written test.

\section{Research Questions}

In relation to the aforementioned gaps in knowledge, this study was conducted to answer the following questions:

a. Is there a significant difference between the TPCK pre-test and posttest scores of the Active MLS group and the Passive MLS group?

b. Do pre-service Physics teachers in the Active MLS group have higher TPCK test scores than those in the Passive MLS group after the intervention?

\section{Methodology}

This study employed a pretest-posttest quasi-experimental design using a mixed-method approach. The study commenced through a permit signed by the university president and the university officials dated on March 17, 2016. The orientation was conducted last April 11, 2016, which included the description of the process of the entire experiment and the distribution of the Informed Consent Form. The TPCK of the participants was measured shortly after the orientation on that same day. The same test was administered after the fiveweek intervention which took place on May 18, 2016 at the Science Building of the university.

\subsection{The Sample}

Eighteen fourth year Bachelor of Secondary Education (BSED) major in Physical Sciences students of a state university in the Eastern Visayas Region of the Philippines participated in the study. Two groups were formed by a random selection of participants through a simple fishbowl technique. Nine pre-service Physics teachers formed the Active Microteaching Lesson Study (MLS) group while the other nine formed the Passive MLS group. Both groups were further divided into three sub-groups with three members each.

The relatively small number of the research participants is due to the limited number of BSED students who take Physical Sciences as their major in the university where the study was conducted. It must be noted that only the preservice teachers who were qualified for practice teaching in the succeeding semester were pre-selected upon which the random selection of group members was based.

The Active MLS group had an average age of 19.00 years, with a range of 18 to 20 years old. Meanwhile, the nine participants in the Passive MLS group had an average age of 19.72 years, with a range of 19 to 22 years old.

All $(100 \%)$ of the Active MLS participants were products of public elementary schools. On the other hand, seven $(77.8 \%)$ from the Passive MLS group graduated from public elementary schools while two $(22.2 \%)$ participants were products of private elementary schools. For their high school background, seven $(77.8 \%)$ from the Active MLS group graduated from public secondary schools, 
whereas, two $(22.8 \%)$ graduated from private high schools. In the Passive MLS group, six $(66.7 \%)$ were products of public secondary schools while three $(33.3 \%)$ were from private high schools.

\subsubsection{Initial comparability in the Academic Performance}

The academic performance of the two groups of participants was compared prior to the experiment. Their ratings in the 13 Science and two Mathematics courses that they have taken before their participation in the study were determined. Data were analyzed through the Mann-Whitney $U$ test using the SPSS Version 23. Table 1 summarizes the results.

Table 1: Mann-Whitney $U$ Test for the Ratings in Science and Mathematics

\begin{tabular}{lcccc}
\hline Subject/Group & $\boldsymbol{N}$ & Mean Rating & Median & $p$ \\
\hline Science & & & & \\
$\quad$ Active MLS & 9 & 1.89 & 1.94 & .863 \\
Passive MLS & 9 & 1.89 & 1.87 & \\
Math & & & & \\
$\quad$ Active MLS & 9 & 1.77 & 1.80 & .489 \\
$\quad$ Passive MLS & 9 & 1.68 & 1.75 & \\
\hline
\end{tabular}

Note: The highest passing rating is 1.00 while the lowest is 3.00; the higher the numerical value, the lower is the rating.

It can be culled from the table that both the Active MLS and the Passive MLS group incurred equal mean rating in Science of 1.89. The Passive MLS group had a slightly higher median rating of 1.87 than the Active MLS group's 1.94. In Mathematics, the Passive MLS group obtained a slightly higher mean and median ratings than the Active MLS group. The analysis suggests that the distribution of the ratings in Science between the Active MLS group and the Passive MLS group was not significantly different $(p=.863)$. In the same manner, the ratings in Mathematics between the two groups were not significantly different $(p=.489)$. These connote that the Active MLS participants were comparable to the Passive MLS participants prior to the experiment.

\subsection{The Instruments}

\section{A. Pre-service Physics Teacher Technological-Pedagogical-Content Knowledge Test (PPT-TPCKT)}

The PPT-TPCKT was a researcher-made test which consisted of 45 multiplechoice items. For TK and PK domains, the correct option was given three points, two points for the partially correct option, and one point for the least probable option. For CK domain, two points were given to the correct choice, one point for the partially correct choice, and no point for the wrong choice. These constitute a total of 120 points, the highest possible score in the test.

The PPT-TPCKT was validated by experts who were active in Science and Mathematics Education research. The instrument was pre-tested to 77 BSEDPhysical Sciences students of two state universities in Region VIII. An overall Cronbach's alpha of .703 for the 45 items was derived from the results of the pretesting procedure. Below is the actual output of the reliability test on the instrument using SPSS 23. 


\section{Reliability}

Case Processing Summary
\begin{tabular}{|ll|r|r|}
\hline & \multicolumn{1}{|c|}{$\mathrm{N}$} & \multicolumn{1}{c|}{$\%$} \\
\hline Cases & Valid & 77 & 79.4 \\
& Excluded $^{\mathrm{a}}$ & 20 & 20.6 \\
& Total & 97 & 100.0 \\
\hline
\end{tabular}

a. Listwise deletion based on all variables in the procedure.

Reliability Statistics

\begin{tabular}{|r|r|r|}
\hline $\begin{array}{c}\text { Cronbach's } \\
\text { Alpha }\end{array}$ & $\begin{array}{c}\text { Cronbach's } \\
\text { Alpha Based on } \\
\text { Standardized } \\
\text { Items }\end{array}$ & N of Items \\
\hline .703 & .716 & 45 \\
\hline
\end{tabular}

\section{B. Interview Protocols}

The researcher collected qualitative data through interviews. Researcher-made interview protocols were prepared which were used during the post-lesson discussions and after the intervention in May 2016.

\section{Journals}

The researcher required a journal from each research participant. The journal was a notebook or a notepad where the participants recorded their day-to-day experiences throughout the intervention. Aside from the descriptions of activities, the journal contained the thoughts and insights of the pre-service Physics teachers while they were implementing the Microteaching Lesson Study. They were prompted to stress the striking or confounding features of the intervention (i.e. Active MLS and Passive MLS).

\subsection{The Active and Passive Microteaching Lesson Study}

The pre-test was administered on April 11, 2016, prior to the actual conduct of the experiment. In the succeeding days, the pre-service Physics teachers from the Active MLS and Passive MLS groups prepared the instructional plans and materials. Moreover, the Active MLS members implemented their instructional plans through microteaching sessions with the Passive MLS members acting as "students".

Nine topics were identified that covered various Physics areas as follows:
1. Law of Acceleration
2. What is Work?: Calculating Work
3. Work is a Method of Transferring Energy
4. Defining Heat and Temperature
5. Phase Change
6. Electric Current, Voltage and Resistance
7. Series and Parallel Connections 


\section{Propagation and Characteristics of Sound \\ 9. Refraction of Light}

Each sub-group prepared three lesson plans and instructional materials. Furthermore, they shared their outputs with the other sub-groups within their respective group, that is, the outputs of one Active MLS sub-group shared their outputs with the remaining two Active MLS sub-group. The same was done by the Passive MLS sub-groups. Figure 2 illustrates the formation of the subgroups.

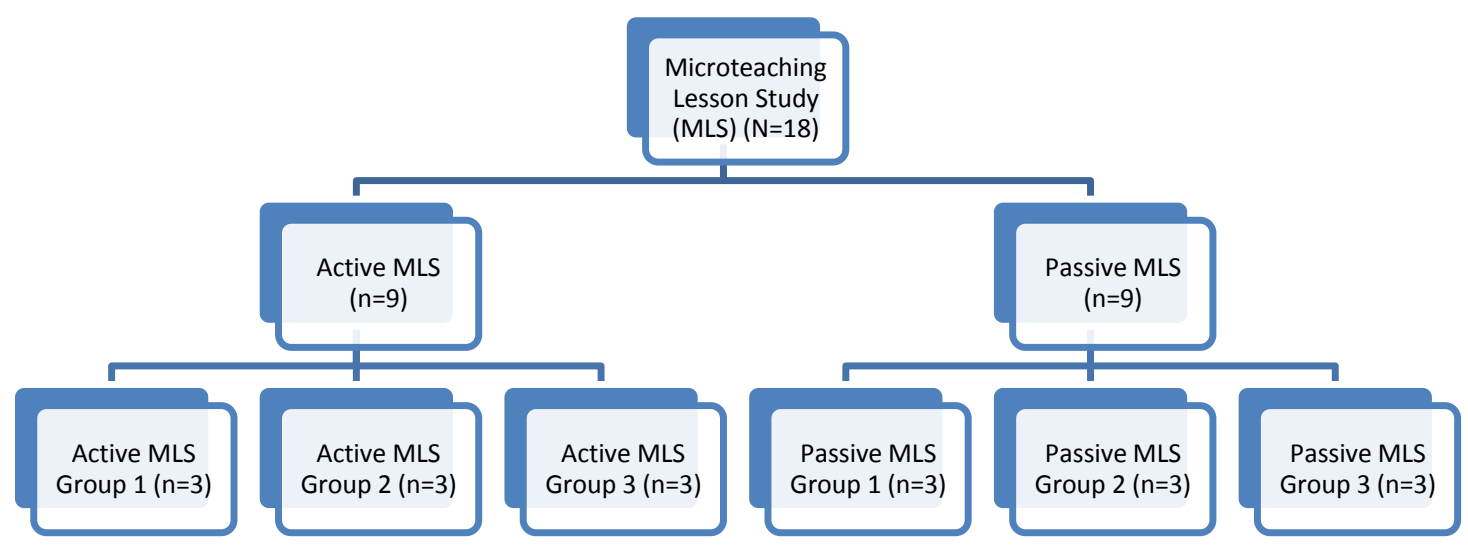

Figure 2. The formation of the Active MLS and the Passive MLS sub-groups.

The Active MLS group carried out all the steps of the typical Lesson Study, namely, (1) establishing goals, (2) planning the lesson, (3) planning the study design, (4) executing the instructional plan, (5) deliberating the lesson implementation, (6) modifying the instructional plan, (7) implementing the revised instructional plan, (8) deliberating the second implementation, and (9) keeping study records. On the other hand, the Passive MLS group did not implement their lesson plans (Steps 4 \& 7), rather, they served as "students" during the lesson implementations of the Active MLS group. This was the case until all the nine topics have been delivered by the three Active MLS subgroups.

Figure 3 summarizes the steps carried out by the Active MLS group and the Passive MLS group. 


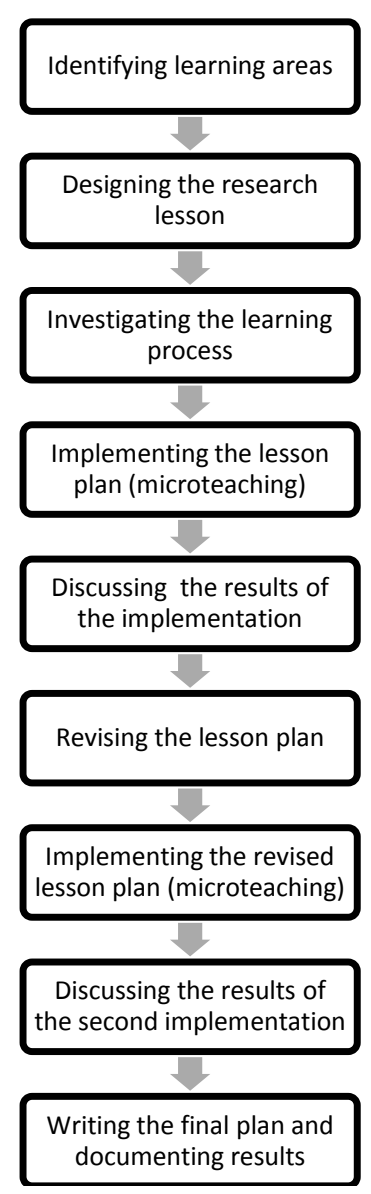

A. Active MLS

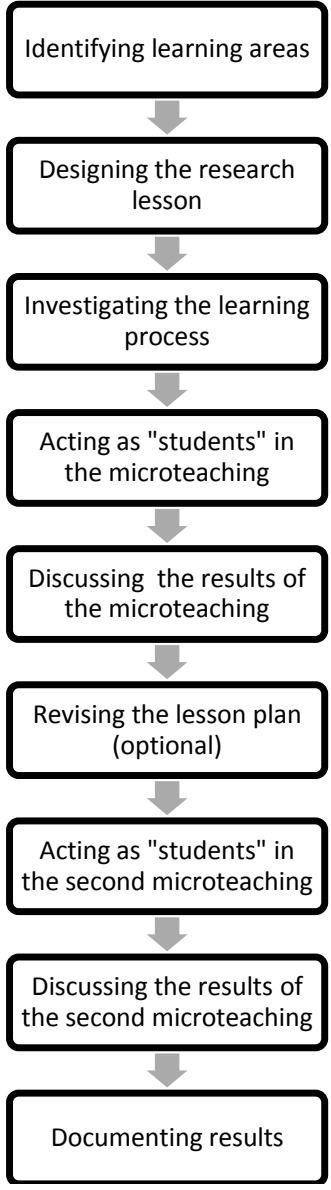

B. Passive MLS

Figure 3. The (a) Active MLS and the (b) Passive MLS Procedures

\subsection{Data Analysis Procedure}

Data were analyzed using the Mann-Whitney $U$ Test to determine significant differences in the scores between the Active MLS group and the Passive MLS group both in the pre-test and post-test of the TPCK test. Meanwhile, the Wilcoxon Signed Ranks Test was employed to analyze within-group differences between pre-test and post-test scores. An alpha of $\alpha=.05$ level of significance was set for all these tests.

The qualitative data were analyzed using the conceptual content analysis technique and the constant comparative method. Selected responses were used to support quantitative findings.

\section{Results/Findings}

\subsection{Initial Comparability and Effect of the Microteaching Lesson Study on TPCK}

Table 2 presents the pre-test and post-test results of the overall TPCK Test. It can be shown that although the Active MLS group obtained a higher mean score (97.56, 81.3\%) than the Passive MLS group (94.44, 78.7\%), the difference in the scores between the two groups is not significant $(p=.605)$. This suggests that the 
two groups are comparable in terms of Technological Pedagogical Content Knowledge before their participation in the study.

Table 2: Mann-Whitney $U$ Test for the Technological-Pedagogical-Content Knowledge Pre-test and Post-test

\begin{tabular}{|c|c|c|c|c|}
\hline Test/Group & $N$ & $\begin{array}{c}\text { Mean Score } \\
(\text { Max. }=120)\end{array}$ & $\begin{array}{c}\text { Median Score } \\
(\text { Max. }=120)\end{array}$ & $p$ \\
\hline \multicolumn{5}{|l|}{ Pre-test TPCK } \\
\hline Active MLS & 9 & $97.56(81.3 \%)$ & $98.00(81.7 \%)$ & \multirow{2}{*}{.605} \\
\hline Passive MLS & 9 & $94.44(78.7 \%)$ & $92.00(76.7 \%)$ & \\
\hline \multicolumn{5}{|l|}{ Post-test ТPCK } \\
\hline Active MLS & 9 & $105.0(87.5 \%)$ & $103.0(85.8 \%)$ & \multirow{2}{*}{$.019^{*}$} \\
\hline Passive MLS & 9 & $98.67(82.2 \%)$ & $100.0(83.3 \%)$ & \\
\hline
\end{tabular}

Note: ${ }^{*} \mathrm{p}<.05$

Interestingly, the post-test results showed that the Active MLS group ( $M n=105.0$, $M d=103.0)$ scored significantly higher than the Passive MLS group ( $M n=98.67$, $M d=100.0$ ), with a p-value of $p=.019$ derived from the Mann-Whitney $U$ test analysis.

Further analysis of the individual effects of the two instructional interventions is shown in Table 3. Results revealed significant improvements in the scores of both the Active MLS group and the Passive MLS group from the pre-test to the post-test ( $p=.008$ and $p=.020$, respectively). These suggest that both the Active MLS and the Passive MLS are effective at developing the overall TPCK of the pre-service Physics teachers, however, the Mann-Whitney $U$ test and the Wilcoxon Signed Ranks test analyses suggest that the Active MLS is more effective than the Passive MLS.

Table 3: Wilcoxon Signed Ranks Test for the Technological-Pedagogical-Content Knowledge Pre-test and Post-test

\begin{tabular}{lcccc}
\hline Group & $\boldsymbol{N}$ & $\begin{array}{c}\text { Pre-test Mean Score } \\
\text { (Max.=120) }\end{array}$ & $\begin{array}{c}\text { Post-test Mean } \\
\text { Score } \\
(\text { Max.=120) }\end{array}$ & $p$ \\
\hline Active MLS & 9 & $97.56(81.3 \%)$ & $105.0(87.5 \%)$ & $.008^{*}$ \\
Passive MLS & 9 & $94.44(78.7 \%)$ & $98.67(82.2 \%)$ & $.020^{*}$ \\
\hline
\end{tabular}

\subsection{Effects of the Microteaching Lesson Study on Pre-service Physics Teachers' TK, PK, and CK}

Table 4 summarizes the mean and median scores of the Active MLS and Passive MLS group per component of the TPCK pre-test and post-test. It can be shown that there was no significant difference in the scores of the two groups across all components of the TPCK pre-test given that $p$-values of $p=.221, p=.063$, and $p=.863$ were derived from the Mann-Whitney $U$ test analyses for the TK, PK, and CK components, respectively. These suggest that the TK, PK, and CK of the Active MLS group were comparable to that of the Passive MLS group before they participated in the study. 
Table 4: Summary Table for the Mann-Whitney $U$ Test on TPCK Components

\begin{tabular}{lcccc}
\hline Test/Group & $N$ & Mean Score & Median Score & $p$ \\
\hline Pre-test TK (Max.=45) & 9 & $41.00(91.1 \%)$ & $41.00(91.1 \%)$ & .221 \\
$\quad$ Active MLS & 9 & $39.44(87.6 \%)$ & $40.00(88.9 \%)$ & \\
$\quad$ Passive MLS & 9 & $40.78(90.6 \%)$ & $41.00(91.1 \%)$ & .436 \\
\hline Post-test TK (Max.=45) & 9 & $39.89(88.6 \%)$ & $40.00(88.9 \%)$ & \\
$\quad$ Active MLS & & & & \\
$\quad$ Passive MLS & 9 & $38.33(85.2 \%)$ & $39.00(86.7 \%)$ & .063 \\
\hline Pre-test PK (Max.=45) & 9 & $36.33(80.7 \%)$ & $37.00(82.2 \%)$ & \\
$\quad$ Active MLS & 9 & $39.89(88.6 \%)$ & $39.00(86.7 \%)$ & $.050^{*}$ \\
$\quad$ Passive MLS & 9 & $37.33(83.0 \%)$ & $37.00(82.2 \%)$ & \\
\hline Post-test PK (Max.=45) & & & & \\
$\quad$ Active MLS & 9 & $18.22(60.7 \%)$ & $18.00(60.0 \%)$ & .863 \\
$\quad$ Passive MLS & 9 & $18.67(62.2 \%)$ & $18.00(60.0 \%)$ & \\
\hline Pre-test CK (Max.=30) & & & \\
$\quad$ Active MLS & 9 & $23.78(79.3 \%)$ & $25.00(83.3 \%)$ & $.024^{*}$ \\
$\quad$ Passive MLS & 9 & $20.78(69.3 \%)$ & $22.00(73.3 \%)$ & \\
\hline Post-test CK (Max.=30) & &
\end{tabular}

Note: ${ }^{*} \mathrm{p}<.05$

Results further showed that the Active MLS group significantly outperformed the Passive MLS group in the PK and CK components of the TPCK post-test ( $p=.050$ and $p=.024$, respectively). However, although the Active MLS $(M n=40.78, M d=41.00)$ performed better than the Passive MLS group $(M n=39.89$, $M d=40.00)$ in the TK component of the post-test, no significant difference was observed between the scores of two groups $(p=.436)$.

No significant differences in the pre-test and post-test scores of both groups in the TK and PK components were revealed by the Wilcoxon Signed Ranks Test as shown in Table 5. Nevertheless, the analysis showed that the Active MLS group obtained a significantly higher score in the CK post-test than the CK pre-test ( $p=$ .012) while no significant change in the scores was observed in the Passive MLS group. These suggest that the Active MLS was more effective at developing the CK of the pre-service Physics teachers.

Table 5: Summary Table for the Wilcoxon Signed Ranks Test on TPCK Components

\begin{tabular}{lcccc}
\hline Component/Group & $N$ & $\begin{array}{c}\text { Pre-test Mean } \\
\text { Score }\end{array}$ & $\begin{array}{c}\text { Post-test Mean } \\
\text { Score }\end{array}$ & $p$ \\
\hline TK (Max.=45) & 9 & $41.00(91.1 \%)$ & $40.78(90.6 \%)$ & .796 \\
$\quad$ Active MLS & 9 & $39.44(87.6 \%)$ & $39.89(88.6 \%)$ & .157 \\
\hline Passive MLS & & & & \\
\hline PK (Max.=45) & 9 & $38.33(85.2 \%)$ & $39.89(88.6 \%)$ & .120 \\
$\quad$ Active MLS & 9 & $36.33(80.7 \%)$ & $37.33(83.0 \%)$ & .259 \\
$\quad$ Passive MLS & & & & \\
CK (Max.=30) & 9 & $18.22(60.7 \%)$ & $23.78(79.3 \%)$ & $.012^{*}$ \\
$\quad$ Active MLS & 9 & $18.67(62.2 \%)$ & $20.78(69.3 \%)$ & .258 \\
\hline Passive MLS & & & & \\
\hline
\end{tabular}




\section{Discussion}

Results of this study support the findings of Cavin (2007) and Chew \& Lim (2013) that a Microteaching Lesson Study pose benefits to various aspects of preservice teachers' Technological Pedagogical Knowledge. Exposing the preservice teachers, primarily to Active MLS, can be beneficial in enhancing their overall TPCK, PK, and CK.

Cajkler, Wood, Norton, Pedder, \& Xu, (2015), Quilario (2014), Hixon (2009), and Kolenda (2007) reported that Lesson Study can be an avenue of promoting teamwork and teaching reflections, reinforcing self-efficacy, and suppressing isolationism. The claims are affirmed by the response of one participant in the Active MLS group when asked how the MLS influenced her:

For me, Sir, it was both awesome and at the same time backbreaking experience. How come? Because it paved a way to a lot of experiences. I also believe that because of the lesson study, it helped me build enough courage and enough confidence to face in front [of the class], especially during summer (Phase 1, Microteaching MLS)... (Participant E18 of the Active MLS Group; Interview, August 25, 2016).

These auspicious results may be explained by Knowles' (1984) Theory of Adult Learning. It contends that establishing a cooperative learning environment can maximize learning. The collaborative instructional planning and preparation of instructional materials in the Microteaching Lesson Study have developed the technological, pedagogical, and content knowledge of the pre-service Physics teachers. More importantly, the implementation of the instructional plans by the Active MLS group provided direct interaction with educational technologies, hands-on experience with pedagogical techniques, and an actual presentation of the subject matter. These engagements have influenced positively the overall TPCK of the pre-service teachers (Cavin, 2007; Cerbin \& Kopp, 2006). Moreover, the post-lesson discussions provided real-time assessment and reflection on the implemented lessons that enhanced their Pedagogical Knowledge (PK). Consequently, the scientific conceptions on Physical ideas have been reinforced through the constant interaction with the MLS groupmates, with the "students" during the implementation of lessons in the microteaching sessions, and with the "experts" in the field through the subject teacher and the researcher. Indeed, the Active Microteaching Lesson Study provided a rich collaborative learning climate to the pre-service teachers (Laal \& Laal, 2012; Lewis et al., 2004; Knowles, 1984).

The non-significant difference in the TK between the Active MLS group and the Passive MLS group may be attributed to some procedural constraints. First, there may have been an insufficient lesson implementation by the Active MLS group. Only one topic was demonstrated by each member, hence, exploration and utilization of an array of educational technologies were not amplified. Second, the TK of the participants may have not been adequately measured by the written test. Employment of other techniques such as evaluation of the instructional materials may be necessary to comprehensively describe the TK of 
the pre-service teachers (Morrison \& Luttenegger, 2015; Choy, Wong, Lim, \& Chong, 2013).

\section{Implication to Research and Practice}

As a perennial educational practice among in-service and pre-service teachers, the individualistic instructional planning and implementation of lessons essentially create an isolated teaching environment that often impedes a myriad of potentials. Providing opportunities for collaborative instructional planning and lesson implementation prior to practice teaching can scaffold pre-service teachers' overall TPCK, TK, PK, and CK. Teacher Education Institutions (TEIs) may provide adequate hands-on experiences on the teaching-learning process to build their confidence and their instructional knowledge system as a preparation for their future career.

Feedback on lesson implementations plays an integral part in the development of the didactic knowledge system of the pre-service teachers. Providing objective and holistic assessment of teaching demonstrations or lesson implementations is imperative in the teacher education curriculum. Emphasis may be specially placed on correcting misconceptions, selecting appropriate methodologies and materials, employing assessment methods, and other relevant aspects.

A single method may be inadequate in assessing the instructional competence of pre-service teachers. Multiple approaches to examining the overall TPCK and its subsequent domains is indispensable for a holistic insight of this construct. Teaching observations, instructional materials evaluation, written tests, oral examinations, and other related techniques must be undertaken in teacher education classrooms to encourage multiple-data sources of learning assessment.

\section{Conclusion}

This research aimed to determine the effects of the Active MLS and the Passive MLS on pre-service Physics teachers' Technological Pedagogical Content Knowledge (TPCK) and on its components. Results revealed that:

- The Active MLS group scored significantly higher $(p=.019)$ than the Passive MLS group in the overall TPCK test after the intervention.

- Both the Active MLS group and the Passive MLS group incurred significantly higher overall score in the TPCK post-test $(p=.008$ and $p=.020$, respectively) than in the pre-test.

- The Active MLS group scored significantly higher than the Passive MLS group in the PK component $(p=.050)$ and in the CK component $(p=.024)$ after the intervention. No significant difference in the group scores was observed in the TK component of the TPCK post-test.

- The Active MLS group obtained a significantly higher post-test score than the pre-test score in the CK component $(p=.012)$. No significant increase in the group scores was observed in the PK and TK components. 
- No significant increase in the group scores of the Passive MLS group was observed in the TK, PK, and CK components.

These findings indicate that both the Active MLS and the Passive MLS can improve the overall TPCK of the pre-service teachers. Results further suggest that the Active Microteaching Lesson Study is more effective at developing the overall TPCK, PK, and CK of the pre-service teachers than the Passive MLS. These imply that the collaborative instructional planning and lesson implementations are potential didactic approaches for an enhanced pre-service teacher education curriculum.

\section{Recommendations}

In relation to the findings of the study, the integration of the Active Microteaching Lesson Study with a larger number of pre-service teachers in different academic areas or specialization (e.g. Biological and Physical Sciences, Mathematics, Social Sciences, English, Filipino, and Technology and Livelihood Education) may be endeavored. A collaborative approach to lesson planning and lesson implementation through Active Microteaching may generate various impressions on different samples and on larger groups.

Likewise, examining TK, PK, and CK from multiple-data sources may be carried out in future research. Assessment methods involving teaching observations and learning outputs such as lesson plans and instructional materials may be undertaken.

Finally, the application of Lesson Study in the Practice Teaching stage of the preservice teachers can be a worthwhile consideration to examine its effects on the actual teaching performance and the TPCK of the pre-service teachers. The use of microteaching as a scaffold to practice teaching may, likewise, be investigated.

\section{Acknowledgment}

The author acknowledges the professional and financial support of the Leyte Normal University, Commission on Higher Education, University of the Philippines Open University, DepEd Tacloban City Division, Leyte National High School, Eastern Visayas State University, College of Education UP Diliman, and UP NISMED.

\section{References}

Alev, N., Karal-Eyuboglu, I., \& Yigit, N. (2012). Examining pre-service physics teachers' pedagogical content knowledge (PCK) with Web 2.0 through designing teaching activities. Procedia - Social and Behavioral Sciences 46, 5040 - 5044.

Akkuş, H., Üner, S. (2017). The Effect of microteaching on pre-service Chemistry teachers' teaching experiences. Cukurova University Faculty of Education Journal, 46 (1), 202-230. doi:10.14812/cuefd.309459. 
Archambault, L., \& Crippen, K. (2009). Examining TPACK among K-12 online distance educators in the United States. Contemporary Issues in Technology and Teacher Education, 9(1), 71-88.

Barrett, D., Riggs, L., \& Ray, J. (2013). Teachers' collaborative use of the lesson study approach to foster student achievement in Geometry. International Journal of Social Sciences \& Education, 3(4), 1188-1192.

Cajkler, W., Wood, P., Norton, J., Pedder, D., \& Xu, H. (2015). Teacher perspectives about lesson study in secondary school departments: A collaborative vehicle for professional learning and practice development. Research Papers in Education, 30(2), 192-213.

Cavin, R. (2007). Developing technological pedagogical content knowledge in preservice teachers through microteaching lesson study. Published Dissertation. Ann Arbor, MI: ProQuest Information and Learning Center/UMI.

Cerbin, W., \& Kopp, B. (2006). Lesson study as a model for building pedagogical knowledge and improving teaching. International Journal of Teaching and Learning in Higher Education, 18(3), 250-257.

Chai, C. S., Koh, J. H., \& Tsai, C.-C. (2010). Facilitating preservice teachers' development of technological, pedagogical, and content knowledge (TPACK). Educational Technology \& Society, 13 (4), 63-73.

Chang, Y., Tsai, M.-F., \& Jang, S.-J. (2014). Exploring ICT use and TPACK of science teachers in two contexts. US-China Education Review A, 4(5), 298-311.

Chew, C., \& Lim, C. (2013). Developing pre-service teachers' technological pedagogical content knowledge for teaching mathematics with the geometer's sketchpad through lesson study. Journal of Education and Learning, 2(1), 1-8.

Choy, D., Wong, A., Lim, K., \& Chong, S. (2013). Beginning teachers' perceptions of their pedagogical knowledge and skills in teaching: A three-year study. Australian Journal of Teacher Education, 38(5), 68-79.

Cox, S. (2008). A conceptual analysis of the technological pedagogical content knowledge. Published Dissertation. Ann Arbor: Proquest LLC/UMI.

Elipane, L. (2012). Integrating the essential elements of lesson study in pre-service mathematics teacher education. Published Dissertation. Copenhagen: Department of Science Education, Copenhagen University.

Ervin, L. (2014). Assessing student learning with teachnology: A descriptive study of technology-using teacher practice and technological pedagogical content knowledge. Published Dissertation. Ann Arbor: ProQuest LCC/UMI.

Fernandez, C. (2002). Learning from Japanese approaches to professional development: The case of lesson study. Journal of Teacher Education, 53(5), 393-405. doi:10.1177/002248702237394.

Gurl, T. (2009). An analysis of an adaptation of lesson study with preservice secondary mathematics teachers. Published Dissertation. Ann Arbor, MI: ProQuest LLC/UMI.

Haley-Mize, S. (2011). The effect of instructional methodology on pre-service educators' level of technological pedagogical content knowledge. Ann Arbor, MI: ProQuest LLC/UMI.

Harris, J., Phillips, M., Koehler, M., \& Rosenberg, J. (2017). TPCK/TPACK research and development: Past, present, and future directions. Australasian Journal of Educational Technology, 33(3), i-viii. https://doi.org/10.14742/ajet.3907.

Hixon, M. (2009). Lesson study: A proposed intervention for professional development and student achievement. Published Dissertation. Ann Arbor, MI: ProQuest LLC/UMI.

Holland, D. (2014). Technological pedagogical content knowledge (TPACK) competencies of preservice teachers at a small rural university. Published Dissertation. Ann Arbor, MI: ProQuest LLC/UMI. 
Kanellopoulou, E.M., Darra, M. (2018). The implementation of the lesson study approach to secondary education in Greece: The case of the literature lesson. International Journal of Learning, Teaching and Educational Research, 17(7), 94-105. https://doi.org/10.26803/ijlter.17.7.6.

Knowles, M. (1984). The adult learner: A neglected species (3rd ed.). Houston, TX: Gulf Publishing Company.

Koehler, M., Mishra, P., \& Cain, W. (2013). What is technological pedagogical content knowledge (TPACK)? Contemporary Issues in Technology and Teacher Education, 9(1), 60-70.

Koehler, M., Mishra, P., Akcaoglu, M., \& Rosenberg, J. (2013). The technological pedagogical content knowledge framework for teachers and teacher educators. East Lansing, MI: Commonwealth Educational Media Centre for Asia.

Kolenda, R. (2007). Japanese lesson study, staff development, and science education reform - The Neshaminy story. Science Educator, 16(1), 29-33.

Laal, M., \& Laal, M. (2012). Collaborative learning: What is it? Procedia - Social and Behavioral Sciences 31, 491-495.

Lewis, C. (2002). Does lesson study have a future in the united states? Nagoya Journal of Education and Human Development 1, 1-23.

Lewis, C., Perry, R., \& Hurd, J. (2004). A deeper look at lesson study. Educational Leadership, 18-22.

Lewis, C., Perry, R., \& Hurd, J. (2009). Improving mathematics instruction through lesson study: A theoretical model and North American case. Journal of Mathematics Teacher Education, 12, 285-304. doi:10.1007/s10857-009-9102-7.

Lucenario, J., Yangco, R., Punzalan, A., \& Espinosa, A. (2016). Pedagogical content knowledge-guided lesson study: Effects on teacher competence and students' achievement in Chemistry. Education Research International, 2016, 1-9.

McDowell, A. (2010). Preservice teachers' use of lesson study in teaching Nature of Science. Published Dissertation. Georgia State University. https://scholarworks.gsu.edu/msit_diss/65

Mishra, P., \& Koehler, M. (2006). Technological pedagogical content knowledge: A framework for teacher knowledge. Teachers College Record, 108(16), 1017-1054.

Morrison, A., \& Luttenegger, K. (2015). Measuring pedagogical content knowledge using multiple points of data. The Qualitative Report, 20(6), 804-816.

Mudzimiri, R. (2012). A study of the development of technological pedagogical content knowledge (TPACK) in preservice secondary mathematics teachers. Published Dissertation. Ann Arbor, MI: ProQuest LLC/UMI.

Nathan, E. (2009). An examination of the relationship between preservice teachers' level of technology integration self-efficacy (TISE) and level of technological pedagogical content knowledge (TPACK). Published Dissertation. Ann Arbor, MI: ProQuest LLC/UMI.

Niess, M. (2005). Preparing teachers to teach science and mathematics with technology: Developing a technology pedagogical content knowledge. Teaching and Teacher Education 21, 509-523.

Ozturk, I. (2012). Wikipedia as a teaching tool for technological pedagogical content knowledge (TPCK) development in pre-service history teacher education. Educational Research and Review, 7(7), 182-191.

Quilario, K. (2014). Biology modelling-based lesson study: Effects on teacher self-efficacy and student critical thinking. Diliman, Quezon City: Unpublished Master's Thesis, UP College of Education. 
Remesh, A. (2013). Microteaching, an efficient technique for learning effective teaching. Journal of Research in Medical Sciences, 18, 158-63.

Sentumbwe, D. (2018). Student-teachers' experiences of microteaching on an economics methods course. African Research Review, 12(2), 101-108. http://dx.doi.org/10.4314/afrrev.v12i2.10.

Schmidt, D., Baran, E., Thompson, A., Koehler, M., Mishra, P., \& Shin, T. (2009) Technological pedagogical content knowledge (TPACK): The development and validation of assessment instrument for preservice teachers. Journal of Research on Technology in Education, 42(2), 123-149.

Teele, S., Maynard, D., \& Marcoulides, G. (2015). The lesson study process - An effective intervention to reduce the achievement gap. US-China Education Review, 229-243.

Terpstra, M. (2009). Developing technological pedagogical content knowledge: preservice teachers' perceptions of how they learn to use educational technology in their teaching. Published Dissertation. Ann Arbor, MI: ProQuest LLC/UMI.

Tokmak, H., Yelken, T., \& Konokman, G. (2013). Pre-service teachers' perceptions on development of their IMD competencies through TPACK-based activities. Educational Technology \& Society, 16(2), 243-256. 


\section{Appendix A}

\section{Preservice Physics Teacher Technological-Pedagogical- Content Knowledge Test}

Name: Date: Major:

DIRECTIONS: There are fifteen (15) scenarios in this test. Each is followed by three (3) questions provided with three (3) options. Encircle the letter that answers best each question on your answer sheet.

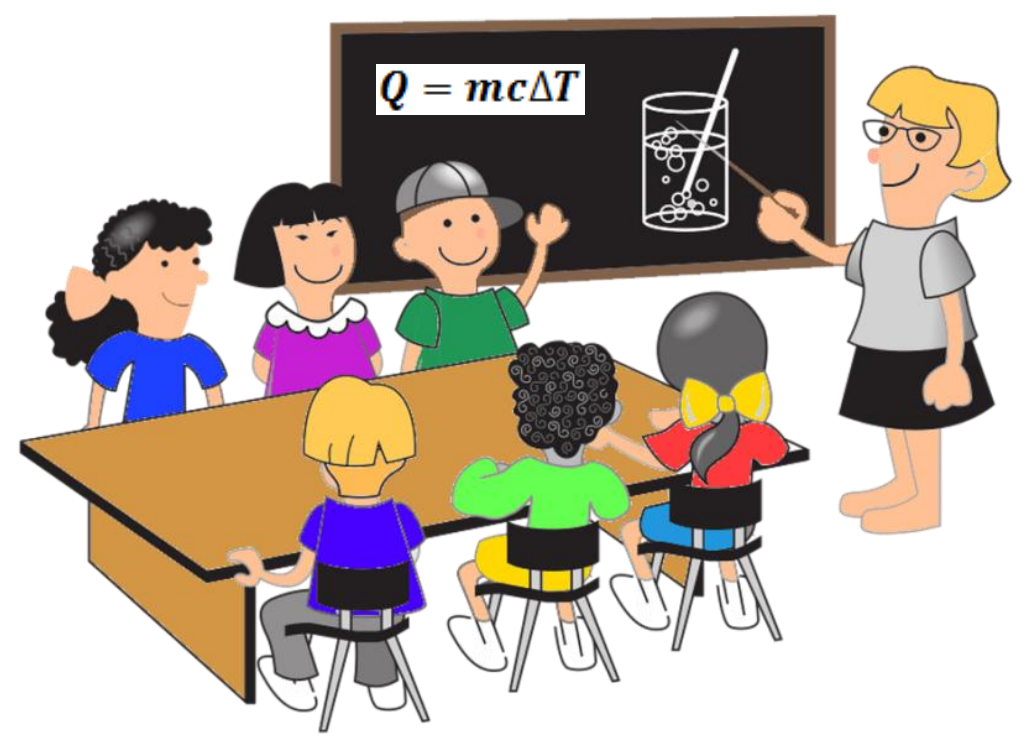

\section{STOP!}




\section{DO NOT TURN TO THE NEXT PAGE UNLESS YOU ARE TOLD TO DO SO. SAMPLE TPCK Test Questions}

Scenario 10: One learning objective of a Physics lesson is "to determine voltage across each load, current and resistance in a series circuit." The teacher decides to conduct a laboratory activity. The students are asked to construct the circuit and to draw a diagram of the set-up.

28. Which of these materials will measure voltage, current, and resistance in the circuit?

a. battery, ammeter and ohmmeter

b. voltmeter, ammeter and ohmmeter

c. voltmeter, battery and diode

29. The teacher asks her students to write a mathematical representation that correctly describes the set-up using these symbols: I-current, V-voltage, and Rresistance. Who among these three students gives the most scientific response?

a. Student 1: $\mathrm{V}=\mathrm{V}_{1}=\mathrm{V}_{2}=\mathrm{V}_{3}$

b. Student 2: $\mathrm{I}=\mathrm{I}_{1}=\mathrm{I}_{2}=\mathrm{I}_{3}$

c. Student 3: V+ $V_{1}=V_{2}+V_{3}$

30. Which circuit diagram correctly describes the set-up?

a.

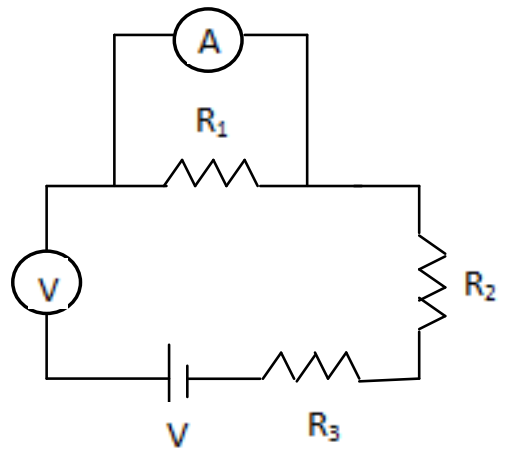

b.

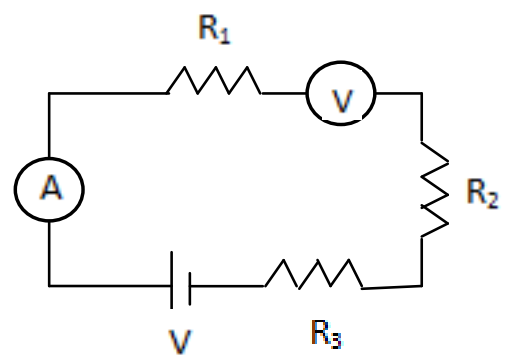

c.

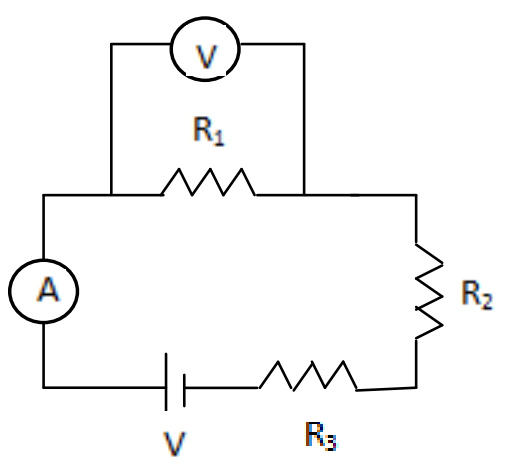

